\title{
PRODUCTION OF BITUMEN MODIFIED WITH LOW-MOLECULAR ORGANIC COMPOUNDS FROM PETROLEUM RESIDUES. 1. EFFECT OF SOLVENT NATURE ON THE PROPERTIES OF PETROLEUM RESIDUES MODIFIED WITH FOLMALDEHYDE
}

\author{
Michael Bratychak ${ }^{1, \bowtie}$, Volodymyr Gunka ${ }^{1}$, Yuriy Prysiazhnyi ${ }^{1}$, \\ Yurii Hrynchuk ${ }^{1}$, Iurii Sidun ${ }^{1}$, Yuriy Demchuk ${ }^{1}$, Olena Shyshchak ${ }^{1}$
}

https://doi.org/10.23939/chcht15.02.274

\begin{abstract}
The possibility of petroleum residues (tar and oxidized bitumen) modification with formaldehyde (37\% aqueous solution) has been studied at the temperature of $393 \pm 3 \mathrm{~K}$ for $3 \mathrm{~h}$ in the presence of organic solvent and using hydrochloric acid as a catalyst. Toluene, $p$-xylene, naphta solvent and $n$-octane were used as the solvents in the amount of $0-40 \mathrm{wt} \%$ relative to the initial material. By means of IR spectroscopy the resin-like compounds affecting the operational properties of petroleum residues have been detected. These compounds are formed as a result of formaldehyde reaction with residue components and solvent molecules.
\end{abstract}

Keywords: petroleum residues, formaldehyde, organic solvents, modified bitumen, IR spectroscopy.

\section{Introduction}

It is known [1-5] that introduction of polymers into the structure of products obtained from petroleum residues improves their operational properties. The amount of introduced polymer additives varies from 1 to $5 \mathrm{wt} \%$ [6]. The production volume of only polymer modified bitumen (PMB) in European countries is $10 \%$ of the total quantity of used bitumen [6]. The following polymers are used to modify bitumen: elastomers (natural and synthetic rubber, rubber crumb); thermoplastics (polyethylene, polypropylene, polyvinyl chloride, etc.); thermoplastic elastomers (styrene-butadiene-styrene; ethylene vinyl acetate, ethylene-propylene-diene, etc.); thermosetting plastics (epoxy resins, polyurethane resins, etc.) [1]. Nowadays thermoplastics and thermoplastic elastomers are used most often $[1,6,7]$.

\footnotetext{
${ }^{1}$ Lviv Polytechnic National University

12, S.Bandery St., 79013 Lviv, Ukraine

mbratychak@gmail.com

(CBratychak M., Gunka V., Prysiazhnyi Y., Hrynchuk Y., Sidun I., Demchuk Y., Shyshchak O., 2021
}

Styrene-butadiene-styrene (SBS) is the most often used modifier for PMB production [8, 9]. The modified bitumens are divided into bitumen-polymer and polymerbitumen binders depending on polymer content. At relatively low content of SBS $(<3.5 \mathrm{wt} \%)$ bitumen are characterized by higher penetration and softening temperature in comparison with original bitumen; its elasticity is about $85-90 \%[10,11]$.

Last decades the scientific researchers of the Department of Chemical Technology of Oil and Gas Processing at Lviv Polytechnic National University have been conducting studies on possibility of using petroleum [12-14], phenol-formaldehyde [15], epoxy [16], coumarone-indene [17] and phenol-cresol-formaldehyde [18-22] resins as polymeric additives.

The above mentioned resins contain free epoxy, carboxy, hydroxyl and methacrylic groups in their structure. They are compatible with petroleum residues and improve operational characteristics of bitumen, namely its adhesion to mineral surfaces.

To continue the investigations regarding the improvement of operational characteristics of the materials based of petroleum residues, this work deals with the possibility of obtaining high-quality paving bitumen using formaldehyde. The idea to use formaldehyde for the bitumen production from petroleum residues, e.g. tar, is grounded on the fact that they contain the compounds with aromatic chains [23-24]. On the other hand it is known [20] that in the presence of acid catalysts the aromatic compounds can react with formaldehyde via condensation reaction and participate in the formation of carbon-formaldehyde resins. Naphthalene, anthracene, phenanthrene, fluorine and others serve as aromatic compounds in this case [25].

To our mind, during the process of bitumen production from tar and during bitumen modification, when aromatic compounds, which are contained in petroleum residues, react with formaldehyde, the formation of arene- 
formaldehyde resins will occur. These resins will modify the bitumen properties. However, petroleum residues are viscous systems under the modification conditions (temperature is $393 \mathrm{~K}$ ).

Thus, the aim of this work is to study the effect of solvent amount and nature on the modification of petroleum residues with formaldehyde, in particular the effect on softening temperature, penetration and adhesion to stone of the modified residues.

\section{Experimental}

\subsection{Materials}

The following materials were used for chemical modification of petroleum residues with formaldehyde:

- Tar produced at JSC Ukrtatnafta (Kremenchuk, Ukraine). Its characteristic is given in Table 1, designated as T1.

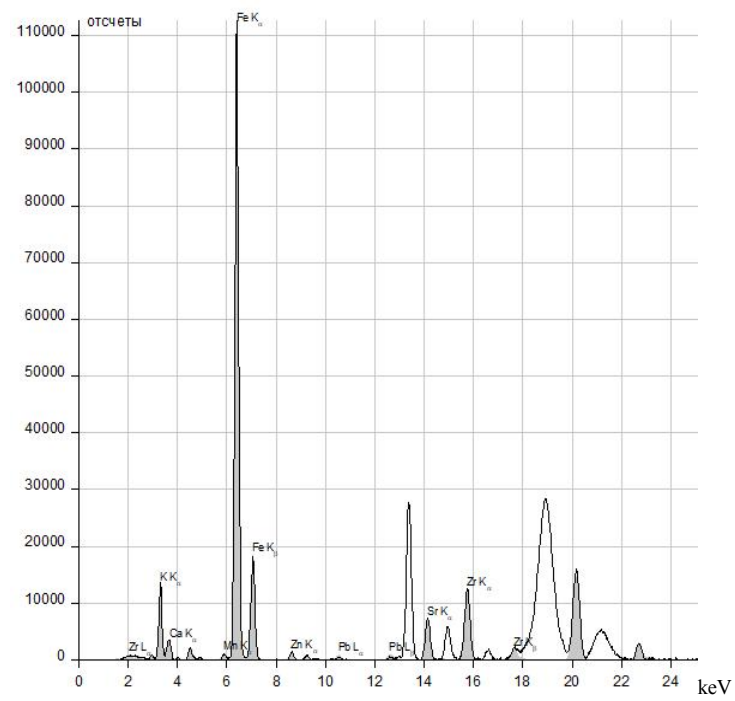

Fig. 1. XRF spectrum of stone heavy elements
- Paving bitumen BND 70/100 (oxidized bitumen) produced at JSC Ukrtatnafta (Kremenchuk, Ukraine). Its characteristic is given in Table 2,designated as $\mathrm{BO} 1$.

- Formaldehyde $(37 \%$ aqueous solution, formalin) was used as a modifier.

- Hydrocloric acid $\left(37 \%\right.$,density $\left.1.19 \mathrm{~g} / \mathrm{cm}^{3}\right)$ of P.A. grade was used as a catalyst.

- Solvents:

- toluene - colorless liquid with specific odor, density of $0.867 \mathrm{~g} / \mathrm{cm}^{3}$ and boiling point of $383.6 \mathrm{~K}$;

- $p$-xylene with density of $0.861 \mathrm{~g} / \mathrm{cm}^{3}$ and boiling point of $411.3 \mathrm{~K}$;

- petroleum solvent with density of $\leq 0.860 \mathrm{~g} / \mathrm{cm}^{3}$ and boiling point of $\geq 403 \mathrm{~K}$;

boiling point of $398.5 \mathrm{~K}$

- $n$-octanewith density of $0.703 \mathrm{~g} / \mathrm{cm}^{3}$ and

To determine a value of adhesion to stone, a natural stone (fraction 5-20 mm) was purchased at JSC Novograd-Volynsky gravel factory (Ukraine). Its characteristic is represented in Figs. 1, 2 and Tables 3, 4.

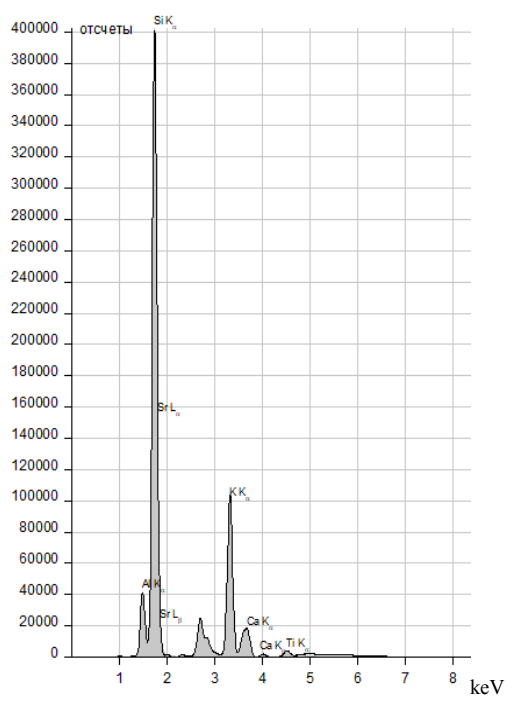

Fig. 2. XRF spectrum of stone light elements

Table 1

\section{Characteristics of $\operatorname{tar} \mathrm{T1}$}

\begin{tabular}{|l|c|c|}
\hline \multicolumn{1}{|c|}{ Index } & Value & Standard or Ref. \\
\hline Flash point (open cup), $\mathrm{K}$ & 555 & ISO 2592:2000 \\
\hline Penetration at $298 \mathrm{~K}, \mathrm{~m} \cdot 10^{-4}(0.1 \mathrm{~mm})$ & 247 & EN 1426:2018 \\
\hline Softening temperature $(\mathrm{R} \& \mathrm{~B}), \mathrm{K}$ & 312 & EN 1427:2018 \\
\hline Ductility at $298 \mathrm{~K}, \mathrm{~m} \cdot 10^{-2}(\mathrm{~cm})$ & 58.1 & EN 13398:2018 \\
\hline Adhesion to crushed stone, points & 3 & {$[21]$} \\
\hline Fraassbreaking point, $\mathrm{K}$ & 255 & EN 12593:2018 \\
\hline Ductile temperature range, $\mathrm{K}$ & 337 & {$[21,22]$} \\
\hline Penetration index & -1.5 & {$[22]$} \\
\hline
\end{tabular}


Characteristics of bitumen BO1

\begin{tabular}{|l|c|c|}
\hline \multicolumn{1}{|c|}{ Index } & Value & Standard or Ref. \\
\hline Penetration at $298 \mathrm{~K}, \mathrm{~m} \cdot 10^{-4}(0.1 \mathrm{~mm})$ & 91 & EN 1426:2018 \\
\hline Softening temperature $(\mathrm{R} \& \mathrm{~B}), \mathrm{K}$ & 321 & EN 1427:2018 \\
\hline Ductility at $298 \mathrm{~K}, \mathrm{~m} \cdot 10^{-2}(\mathrm{~cm})$ & $>100$ & EN 13398:2018 \\
\hline Adhesion to crushed stone, points & 3 & {$[21]$} \\
\hline Fraass breaking point, $\mathrm{K}$ & 253 & EN 12593:2018 \\
\hline Ductile temperature range, $\mathrm{K}$ & 340 & {$[21,22]$} \\
\hline Penetration index & -1.5 & {$[22]$} \\
\hline
\end{tabular}

Table 3

Elemental composition of crushed stone

\begin{tabular}{|c|c|c|c|}
\hline Element & Series & Intensity, rel.units & Concentration, wt \% \\
\hline $\mathrm{Al}$ & $\mathrm{K}$ & 295851 & 6.07 \\
\hline $\mathrm{Si}$ & $\mathrm{K}$ & 3000151 & 25.45 \\
\hline $\mathrm{K}$ & $\mathrm{K}$ & 71229 & 15.40 \\
\hline $\mathrm{Ca}$ & $\mathrm{K}$ & 14977 & 2.73 \\
\hline $\mathrm{Ti}$ & $\mathrm{K}$ & 11603 & 0.77 \\
\hline $\mathrm{Mn}$ & $\mathrm{K}$ & 6370 & 0.10 \\
\hline $\mathrm{Fe}$ & $\mathrm{K}$ & 672667 & 7.08 \\
\hline $\mathrm{Zn}$ & $\mathrm{K}$ & 8806 & 0.03 \\
\hline $\mathrm{Ga}$ & $\mathrm{K}$ & 5401 & 0.01 \\
\hline $\mathrm{Sr}$ & $\mathrm{K}$ & 59667 & 0.03 \\
\hline $\mathrm{Zr}$ & $\mathrm{K}$ & 100842 & 0.05 \\
\hline $\mathrm{Pb}$ & $\mathrm{L}$ & 7643 & 0.01 \\
\hline
\end{tabular}

Table 4

Oxide composition of crushed stone

\begin{tabular}{|c|c|c|c|}
\hline Compound & Series & Intensity, rel.units & Concentration, wt \% \\
\hline $\mathrm{Al}_{2} \mathrm{O}_{3}$ & $\mathrm{~K}$ & 295851 & 11.47 \\
\hline $\mathrm{SiO}_{2}$ & $\mathrm{~K}$ & 3000151 & 54.45 \\
\hline $\mathrm{K}_{2} \mathrm{O}$ & $\mathrm{K}$ & 71229 & 18.55 \\
\hline $\mathrm{CaO}$ & $\mathrm{K}$ & 14977 & 3.82 \\
\hline $\mathrm{TiO}_{2}$ & $\mathrm{~K}$ & 11603 & 1.28 \\
\hline $\mathrm{MnO}$ & $\mathrm{K}$ & 6370 & 0.13 \\
\hline $\mathrm{Fe}_{2} \mathrm{O}_{3}$ & $\mathrm{~K}$ & 672667 & 10.12 \\
\hline $\mathrm{ZnO}_{\mathrm{Ga}_{2} \mathrm{O}_{3}}^{\mathrm{KO}}$ & $\mathrm{K}$ & 8806 & 0.04 \\
\hline $\mathrm{ZrO}_{2}$ & $\mathrm{~K}$ & 5401 & 0.02 \\
\hline $\mathrm{PbO}$ & $\mathrm{K}$ & 59667 & 0.04 \\
\hline & $\mathrm{L}$ & 100842 & 0.06 \\
\hline
\end{tabular}

\subsection{Experimental Procedure}

\subsubsection{Modification of petroleum residues with formaldehyde}

The modification was carried out in hermetic metal vessels capable to withstand an extreme pressure (Fig. 3).
The vessel is loaded with a raw material (tar or bitumen) preheated to the temperature providing its movable state and cooled to the temperature below boiling points of formalin and solvent. Then an organic solvent is added and the mixture is stirred till the homogeneous state. After adding formaldehyde and a catalyst the vessel is closed hermetically, placed into a thermostat, heated to 
$393 \pm 3 \mathrm{~K}$ and kept for $3 \mathrm{~h}$. The mixture is shaken from time to time in order to intensify the process. After $3 \mathrm{~h}$ the vessel is cooled and volatile products are distilled at $363-$ $368 \mathrm{~K}$ and residual pressure of $1.33-1.99 \mathrm{kPa}$. The resulting product is dried in a vacuum cabinet at $393 \mathrm{~K}$ and residual pressure of $2 \mathrm{kPa}$. The product yield, softening temperature, penetration, Fraass breaking point and adhesion to crushed stone are determined.

The modification conditions are shown in Table 5.

\subsection{Methods of Analysis}

\subsubsection{Physico-technological characteristics}

The following physico-technological characteristics of the initial materials and products were determined according to the standard procedures: softening temperature (EN 1427:2018); penetration [22]; Fraass breaking point (EN 12593:2018); adhesion to crushed stone [21].

\subsubsection{Spectral investigations}

IR spectra were recorded using Thermo scientific Nicolet iS10Fourier-spectrophotometer. The results were processed using of the spectrophotometer software.

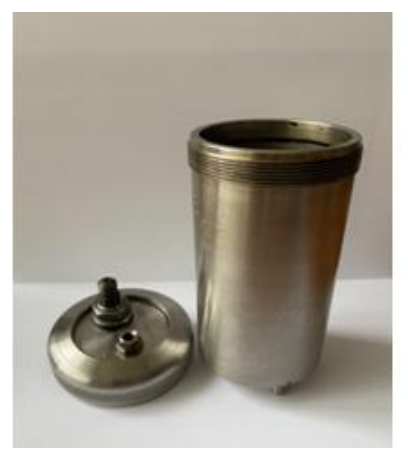

Fig. 3. Vessel for petroleum residues modification

Table 5

Conditions for T1 and BO1 modification with formaldehyde

\begin{tabular}{|c|c|}
\hline Index & Value relative to the initial petroleumresidue, wt \% \\
\hline Formalin amount (including formaldehyde) & $10.0(3.7)$ \\
\hline Catalyst (HCl) amount & 2.5 \\
\hline Solvent & $0-40.0$ \\
\hline
\end{tabular}

Notes: values are calculated per $100 \mathrm{~g}$ of petroleum residue. Toluene, $p$-xylene, naphta solvent, and $n$-octane are the solvents.

\section{Results and Discussion}

The modification process was carried out in a hermetic vessel because formaldehyde is a high-volatile material. On the other hand, the initial petroleum residues are high-viscous components. Taking these facts into consideration it was necessary to examine the effect of the Laboratory of Advanced Technologies for the Creation and Physico-chemical Analysis of New Compounds and Functional Materials (Lviv Polytechnic National University, Ukraine) using ElvaX Light SDD spectrometer (Elvatech Company).

Fluorescence spectrum of light elements (from $\mathrm{Na}$ to $\mathrm{Cl}$ ) was recorded with additional blowdown of the system by helium. For the elements with higher atomic number the spectrum was recorded without helium.

Fluorescence peaks of $\mathrm{K}$ and $\mathrm{Ca}$ are observed in both spectra due to the presence of high- and low-energy internal transitions in these elements.

The interpretation of the spectra was carried out taking into account the localization of the peaks that fall at the energy maximum of the electronic transition or the presence of all maxima of the characteristic transitions.

The quantitative composition was estimated using the device software by the method of deriving the ratios of the peak areas of each individual element to the total peak area of all elements according to the algorithm of fundamental parameters.

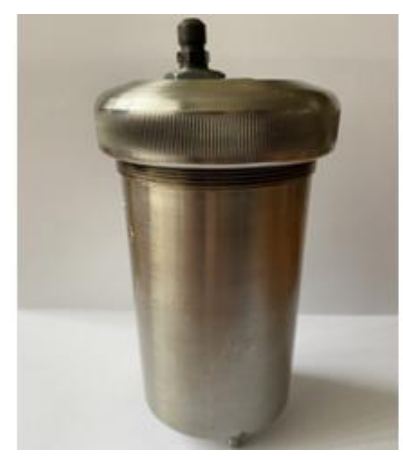


Effect of process conditions on the characteristics of the resulting products

\begin{tabular}{|l|c|c|}
\hline \multirow{2}{*}{ Characteristic of the modified product } & \multicolumn{2}{|c|}{ Process conditions } \\
\cline { 2 - 3 } & \multicolumn{2}{|c|}{ without stirring } \\
\hline Based on T1 & 325 & 323 \\
\hline Softening temperature $(\mathrm{R} \& \mathrm{~B}), \mathrm{K}$ & 41 & 53 \\
\hline Penetration at $298 \mathrm{~K}, \mathrm{~m} \cdot 10^{-4}(0.1 \mathrm{~mm})$ & 270 & 269 \\
\hline Fraass breaking point, $\mathrm{K}$ & 3 & 3 \\
\hline Adhesion to crushed stone, points & & \\
\hline Based on BO1 & 333 & 331 \\
\hline Softening temperature $(\mathrm{R} \& \mathrm{~B}), \mathrm{K}$ & 28 & 33 \\
\hline Penetration at $298 \mathrm{~K}, \mathrm{~m} \cdot 10^{-4}(0.1 \mathrm{~mm})$ & 3 & 3.5 \\
\hline Adhesion to crushed stone, points & & \\
\hline
\end{tabular}

Notes: toluene is a solvent ( $40 \mathrm{wt} \%$ relative to the initial material); temperature is $393 \pm 3 \mathrm{~K}$, time is $3 \mathrm{~h}$. The characteristics of the initial $\mathrm{T} 1$ and $\mathrm{BO} 1$ are given in Tables 1 and 2, respectively.

Table 7

Effect of solvent nature and amount on the characteristics of the resulting products based on T1

\begin{tabular}{|c|c|c|c|c|c|}
\hline $\begin{array}{l}\text { Solvent and its } \\
\text { amount, wt } \%\end{array}$ & $\begin{array}{l}\text { Product yield } \\
\text { relative to the } \\
\text { initial } \mathrm{T} 1 \text {, wt } \%\end{array}$ & $\begin{array}{c}\text { Softening } \\
\text { temperature } \\
\text { (R\&B), K }\end{array}$ & $\begin{array}{l}\text { Penetration at } \\
298 \mathrm{~K}, 0.1 \mathrm{~mm}\end{array}$ & $\begin{array}{c}\text { Fraass breaking } \\
\text { point, } \mathrm{K}\end{array}$ & $\begin{array}{c}\text { Adhesion to } \\
\text { crushed stone, } \\
\text { points }\end{array}$ \\
\hline Without solvent & 107 & 325 & 55 & 264 & 3.5 \\
\hline Toluene, 20 & 108 & 321 & 85 & 267 & 3.0 \\
\hline Toluene, 30 & 109 & 322 & 65 & 268 & 3.0 \\
\hline Toluene, 40 & 112 & 323 & 53 & 269 & 3.0 \\
\hline$p$-Xylene, 20 & 111 & 316 & 118 & 261 & 3.5 \\
\hline$p$-Xylene, 30 & 108 & 318 & 103 & 268 & 3.0 \\
\hline p-Xylene, 40 & 105 & 317 & 93 & 268 & 3.0 \\
\hline Naphta solvent, 20 & 108 & 320 & 73 & - & 3.5 \\
\hline Naphta solvent, 40 & 105 & 321 & 70 & - & 3.0 \\
\hline n-Octane, 20 & 105 & 324 & 78 & 267 & 4.0 \\
\hline n-Octane, 30 & 106 & 324 & 74 & 267 & 3.5 \\
\hline n-Octane, 40 & 101 & 326 & 62 & - & 3.0 \\
\hline
\end{tabular}

Note: for the initial T1 a softening temperature is $312 \mathrm{~K}$, penetration is 247 , adhesion to stone is 2.5 points

Table 8

Effect of solvent nature and amount on the characteristics of the resulting products based on BO1

\begin{tabular}{|c|c|c|c|c|c|}
\hline $\begin{array}{c}\text { Solvent and its } \\
\text { amount, wt\% }\end{array}$ & $\begin{array}{c}\text { Product yield } \\
\text { relative to the } \\
\text { initial T1, wt \% }\end{array}$ & $\begin{array}{c}\text { Softening } \\
\text { temperature } \\
\text { (R\&B), K }\end{array}$ & $\begin{array}{c}\text { Penetration at } \\
298 \mathrm{~K}, 0.1 \mathrm{~mm}\end{array}$ & $\begin{array}{c}\text { Fraass breaking } \\
\text { point, K }\end{array}$ & $\begin{array}{c}\text { Adhesion to } \\
\text { crushed stone, } \\
\text { points }\end{array}$ \\
\hline Without solvent & 103 & 326 & 42 & 268 & 3.5 \\
\hline Toluene, 20 & 106 & 332 & 28 & - & 3.5 \\
Toluene, 40 & 106 & 331 & 33 & - & 3.5 \\
\hline Naphta solvent, 20 & 107 & 326 & 36 & - \\
Naphta solvent, 40 & 105 & 331 & 34 & 269 & 3.5 \\
\hline n-Octane, 20 & 108 & 332 & 26 & 269 & 3.0 \\
n-Octane, 40 & 104 & 332 & 28 & & 3.0 \\
\hline
\end{tabular}

Note: for the initial $\mathrm{BO} 1$ a softening temperature is $319 \mathrm{~K}$, penetration is 70 , adhesion to stone is 2.5 points 
One can see from Tables 7 and 8 that it is possible to obtain improved bitumen via modification of petroleum residues with formaldehyde. The resulting products have a softening temperature of $317 \mathrm{~K}$ and higher; penetration is more than 70 . The value of adhesion is improved as well. At the same time, it is obvious that the solvent has more impact for BO1, which is more viscous material. For example, when $\mathrm{T} 1$ is modified without the solvent, the softening temperature increases by $13 \mathrm{~K}$, whereas when toluene, $p$-xylene, naphta or $n$-octane is used as the solvent ( $40 \mathrm{wt} \%$ ), this value increases by $11,5,9$ or $14 \mathrm{~K}$, respectively. When $\mathrm{BO} 1$ is modified without the solvent (Table 8), the softening temperature increases by $7 \mathrm{~K}$, whereas when toluene, naphta or $n$-octane is used as the solvent ( $40 \mathrm{wt} \%$ ), this value increases by 12,12 or $13 \mathrm{~K}$, respectively.
Apart from the improvement of some indices, the increase in product yield is observed (Tables 7,8 ). This indicates that formaldehyde react with petroleum residue or the solvent. The reaction of formaldehyde molecules and those of petroleum residue is confirmed by the increase in yield after modification without the solvent.

The possible reaction of formaldehyde with the solvent is confirmed by IR spectroscopy. For this purpose the experiments were carried out according to the procedure described in subsection 2.2.1 but without petroleum residues. The ratio formaldehyde : catalyst $(\mathrm{HCl})$ : solvent $=4: 1: 16$ was chosen in such a way, that solvent amount would be $40 \mathrm{wt} \%$. Resin-like products were obtained and analyzed (Figs. 4-7, Table 9). IR spectra of pure solvents were taken for the comparison.

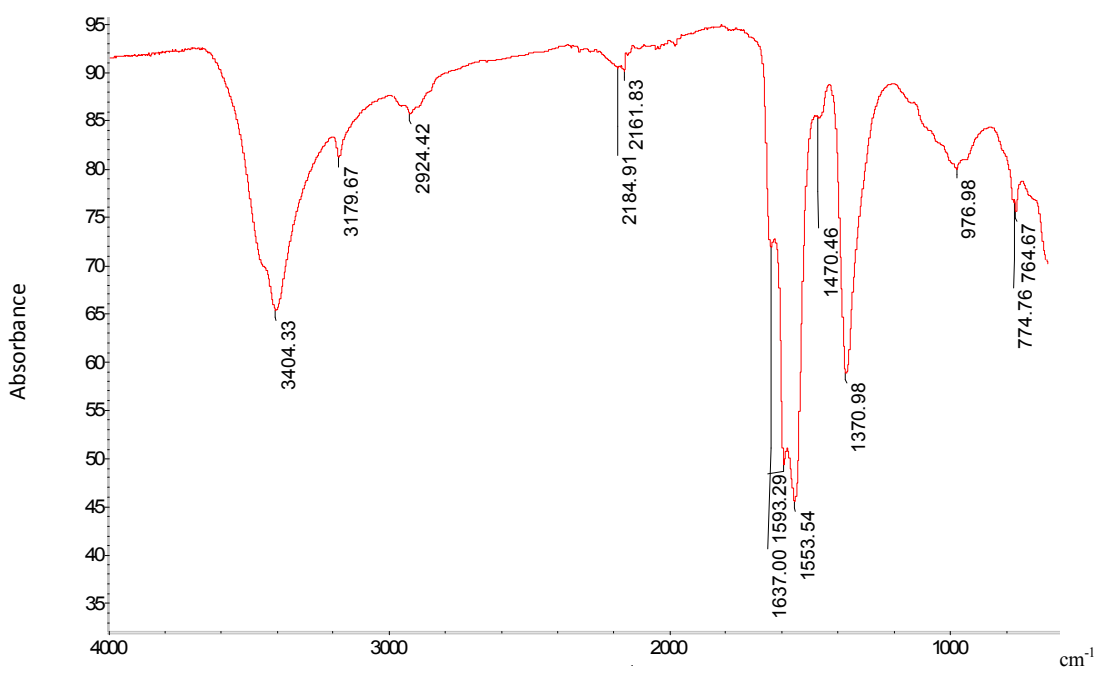

Fig. 4. IR spectrum of the product obtained via reaction of formaldehyde and toluene

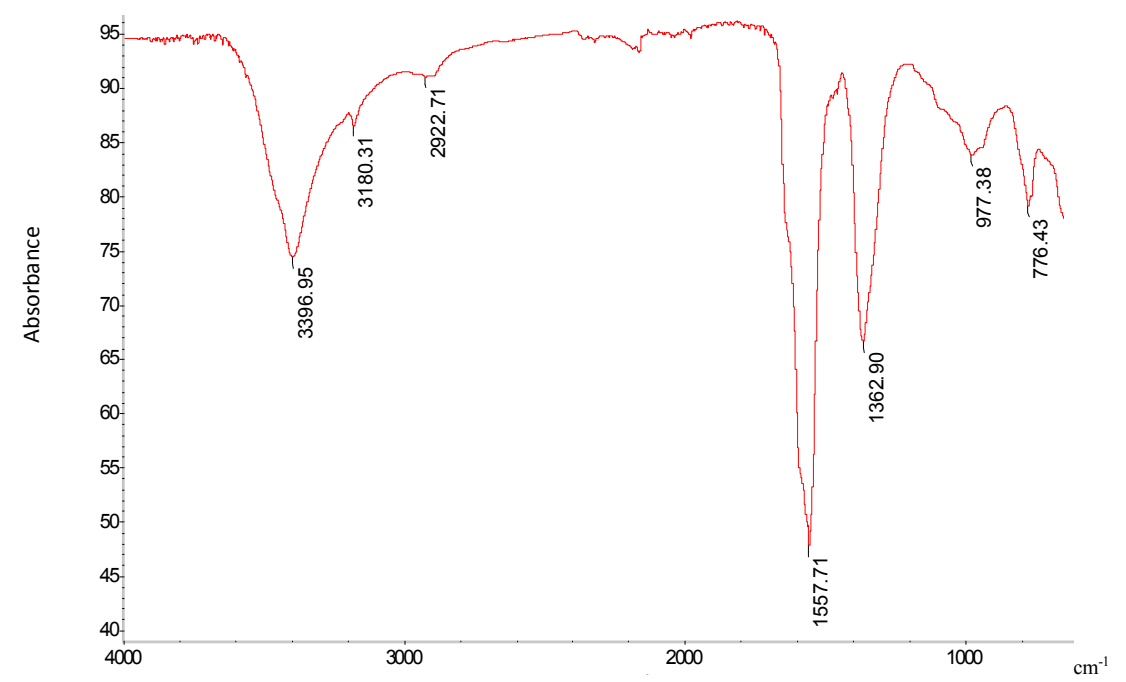

Fig. 5. IR spectrum of the product obtained via reaction of formaldehyde and $p$-xylene 


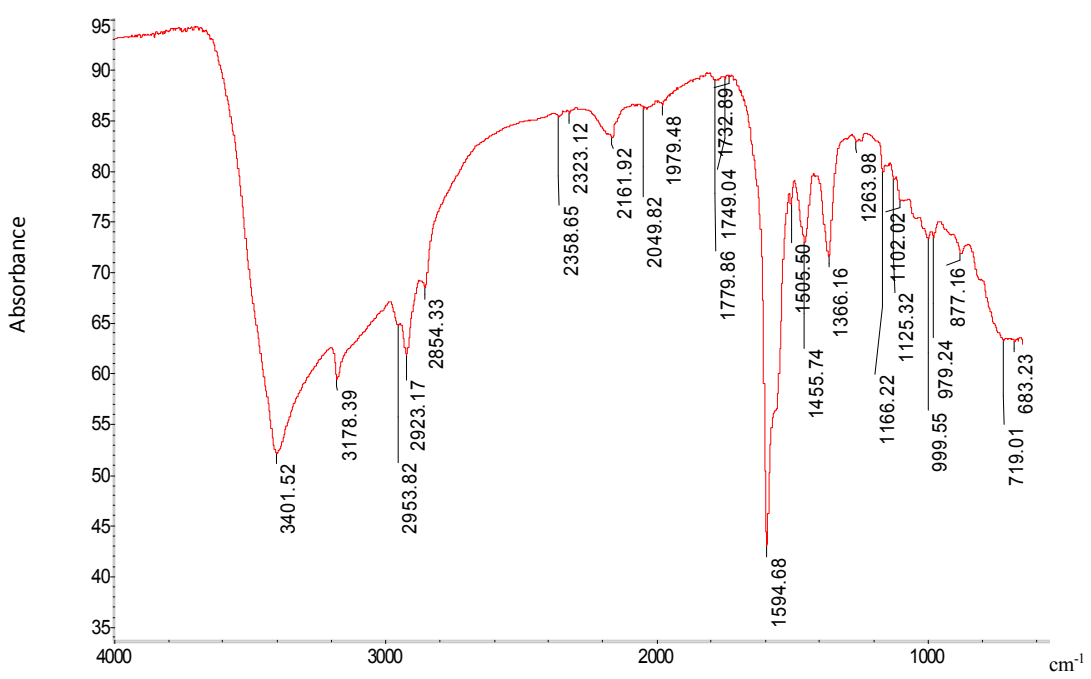

Fig. 6. IR spectrum of the product obtained via reaction of formaldehyde and naphta solvent

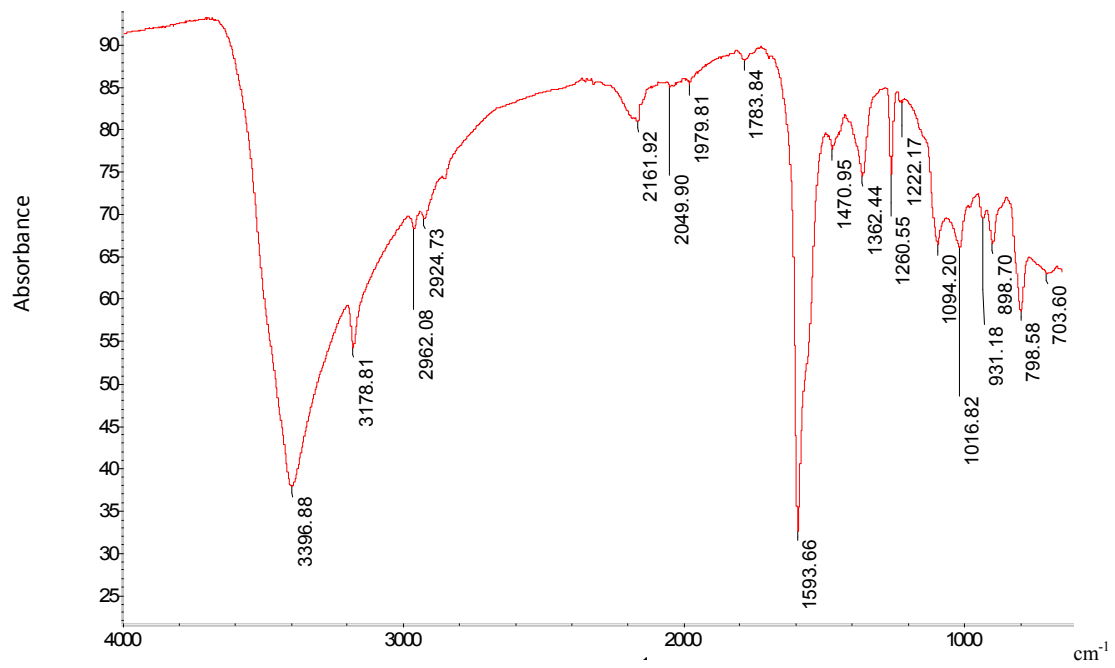

Fig. 7. IR spectrum of the product obtained via reaction of formaldehyde and $n$-octane

Table 9

Yield of resin-like products (areno-formaldehyde resins) and their IR characteristics

\begin{tabular}{|c|c|c|c|c|c|c|c|}
\hline \multirow[b]{2}{*}{ Solvent } & \multirow{2}{*}{$\begin{array}{l}\text { Yield of resin- } \\
\text { like products, } \\
\mathrm{g} / 100 \mathrm{~g} \text { of } \\
\text { formaldehyde }\end{array}$} & \multicolumn{6}{|c|}{ Absorption bands, $\mathrm{cm}^{-1}$} \\
\hline & & $\begin{array}{l}-\mathrm{OH} \\
-\mathrm{c}-\mathrm{Or}\end{array}$ & $-\mathrm{CH}_{3}$ & $-\mathrm{CH}_{2}-$ & & $\begin{array}{l}\text { mono- and } \\
\text { disubstituted } \\
\text { arenes }\end{array}$ & $\begin{array}{c}\text { di- and } \\
\text { trisubstituted } \\
\text { arenes }\end{array}$ \\
\hline Toluene & 80 & $\begin{array}{l}3404 \\
1371\end{array}$ & 3180 & 2924 & 1554 & 775 & 977 \\
\hline$p$-Xylene & 92 & $\begin{array}{l}3397 \\
1363\end{array}$ & 3180 & 2923 & 1558 & 776 & 977 \\
\hline $\begin{array}{l}\text { Naphta } \\
\text { solvent }\end{array}$ & 63 & $\begin{array}{l}3402 \\
1366\end{array}$ & 3178 & 2923 & 1595 & 719 & 877 \\
\hline$n$-Octane & 35 & $\begin{array}{l}3397 \\
1362\end{array}$ & 3179 & 2924 & 1595 & 799 & 899 \\
\hline
\end{tabular}


In the spectrum of the product obtained in the presence of toluene (Fig. 4, Table 9) we observe the absorption band at $1554 \mathrm{~cm}^{-1}$ corresponding to the stretching vibrations of benzene ring. Moreover, this spectrum shows absorption bands at 775 and $977 \mathrm{~cm}^{-1}$ indicating the presence of mono-, di- and trisubstituted benzene rings in the product. If the band at $775 \mathrm{~cm}^{-1}$ may be attributed to $-\mathrm{CH}_{3}$ group of toluene, then di- or trisubstituted benzene rings indicate the reaction of toluene with formaldehyde molecules resulting in the formation of $-\mathrm{CH}_{2}-$ groups. The presence of these groups is confirmed by absorption band at $2924 \mathrm{~cm}^{-1}$.

The absorption bands at 3404 and $1370 \mathrm{~cm}^{-1}$ (Fig. 4) corresponding to $-\mathrm{OH}$ and $\frac{\mathrm{T}}{\mathrm{T}}-\mathrm{OH}$ groups, respectively, arouses the interest.

Thus we assume that during tar modification with formaldehyde in the presence of the catalyst $(\mathrm{HCl})$ and toluene as the solvent, the following reactions occur:

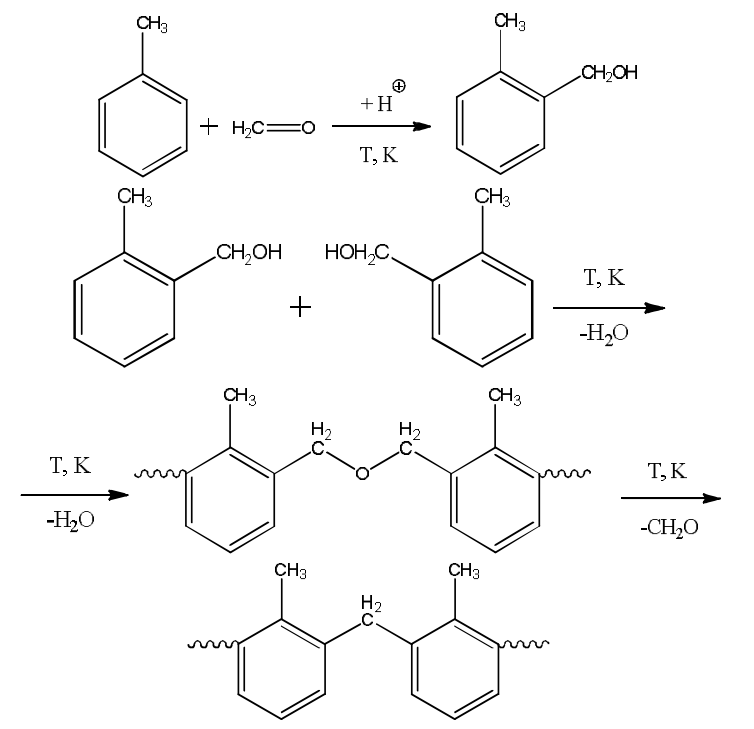

The formation of products according to Eq. (1) is confirmed by the absorption bands at 3404 and $1370 \mathrm{~cm}^{-1}$ typical of stretching vibrations of $-\mathrm{OH}$ and $-\mathrm{CH}_{2} \mathrm{OH}$ groups. The absorption bands at $1270-1020 \mathrm{~cm}^{-1}$ are absent in the spectrum. This indicates that formaldehyde is detached according to Eq. (2) with a high rate followed by the formation of toluene-formaldehyde resin. The absorption bands at 977 and $774 \mathrm{~cm}^{-1}$ confirm this.

The results for the product obtained via reaction of formaldehyde and $p$-xylene are similar (Fig. 5, Table 9).

The formation of xylene-formaldehyde oligomers based on $p$-xylene may be expressed by the following equation:

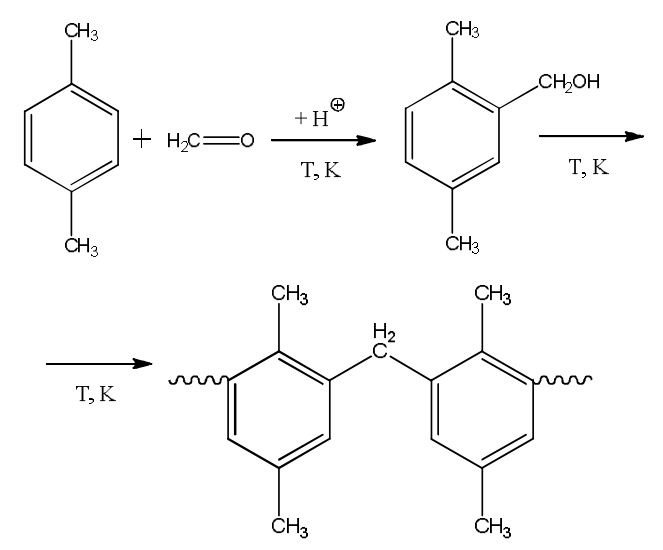

Similar to the previous case, the $p$-xylene based oligomer contains free $-\mathrm{CH}_{2} \mathrm{OH}$ group (3397 and $1363 \mathrm{~cm}^{-1}$, Table 9), which indicates the presence in the resulting product of the mixture that consists of the resulting oligomer and methylol derivatives of $p$-xylene.

Naphta solvent, which is a mixture of xylene isomers, reacts with formaldehyde in a similar way (see Eqs. 1-3). The spectrum of the resulting product is given in Fig. 6 and its interpretation - in Table 9.

Unlike toluene, $p$-xylene and naphta solvent, $n$-octane does not contain aromatic compounds but it is an effective solvent for the modification of tar or bitumen. The product obtained in the presence of $n$-octane is a powdered compound, the spectrum of which is represented in Fig. 7 and its interpretation in Table 9. The absorption band at $1595 \mathrm{~cm}^{-1}$ corresponding to the stretching vibrations of benzene ring is observed. Moreover, there are also the absorption bands at 799 and $899 \mathrm{~cm}^{-1}$ typical of stretching vibrations of di- and trisubstituted aromatic rings. The bands at 3397 and $1362 \mathrm{~cm}^{-1}$ indicate the presence of free $-\mathrm{OH}$ and $=\mathrm{CH}_{2} \mathrm{OH}$ groups, as well as the band at $1094 \mathrm{~cm}^{-1}$ typical of aliphatic ethers ( $\rightleftharpoons \mathrm{c}-\mathrm{O}-\mathrm{c} \rightleftharpoons$ ).

The absorption bands at 3397, 1362 and $1595 \mathrm{~cm}^{-1}$ are absent in the IR spectrum of pure $n$-octane (Fig. 8) indicating the absence of free hydroxyl groups and benzene rings in its structure.

Thus, under the experimental conditions the dehydrocyclization of $n$-octane molecules takes place and benzene structures of the following structure are formed:

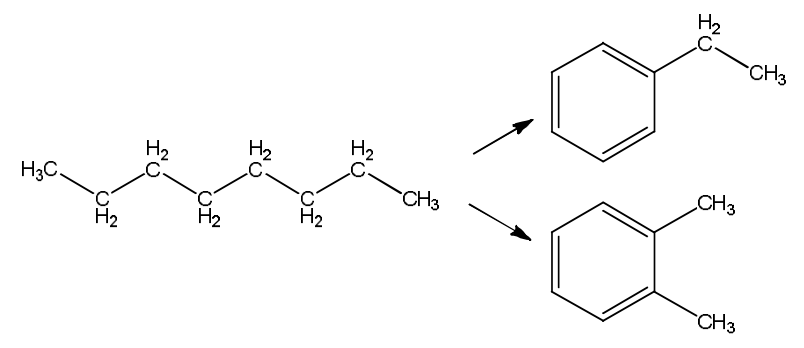




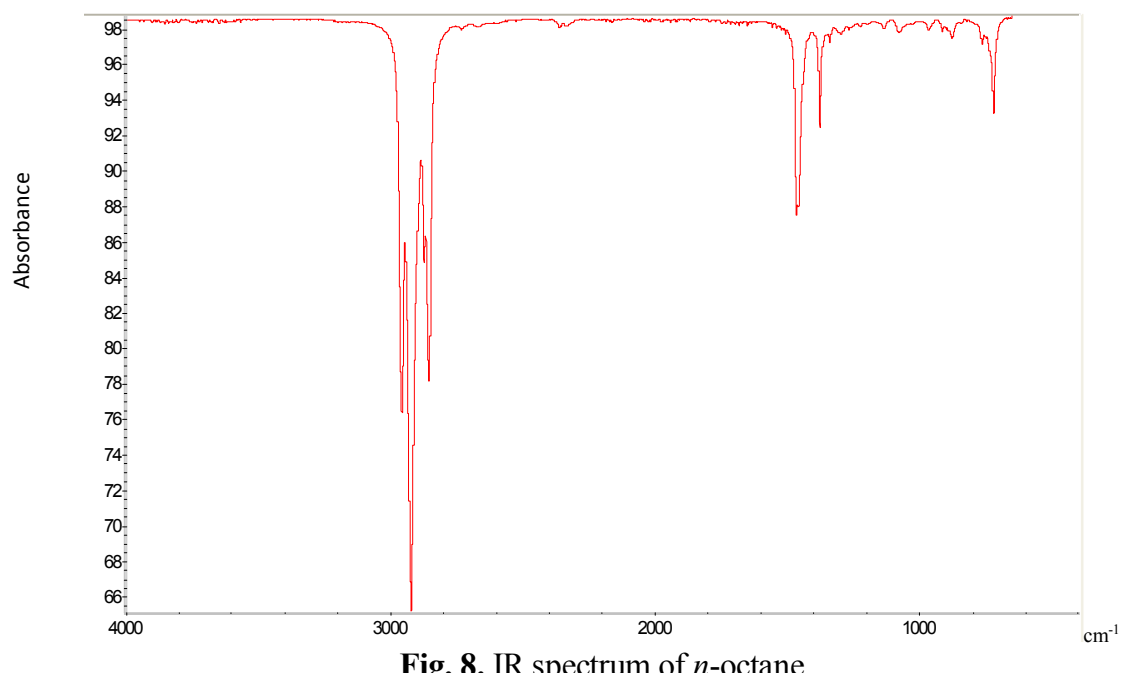

The catalyst of this reaction may be $\mathrm{FeCl}_{3}$, which is formed due to the reaction of hydrochloric acid and metal surface of the vessel used for the synthesis. This is evidenced by the corrosion appeared on the internal surface of the vessel. Aromatic compounds which are formed according to Eq. (4) then react with formaldehyde in accordance with Eqs. (1-3), the same as in the case with toluene, $p$-xylene and naphtha solvent. In addition to the possible conversion of $n$-octane into aromatic compounds occurred under pressure in the presence of the catalyst, the formaldehyde condensation (Eq. 5) is possible too.

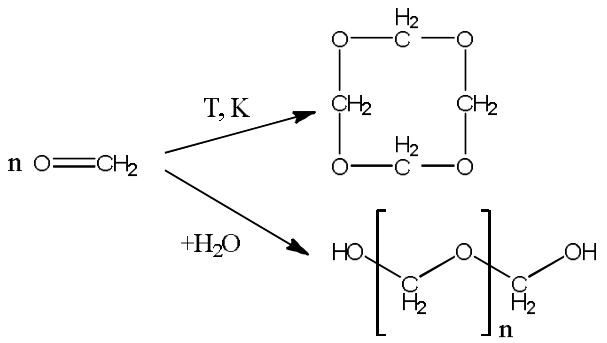

The possibility of reaction (5) proceeding is confirmed by the absorption bands at 3397 and $1362 \mathrm{~cm}^{-1}$ (Fig. 7) indicating the presence of $-\mathrm{OH}$ and $-\mathrm{CH}_{2} \mathrm{OH}$ groups, as well the absorption band at $1094 \mathrm{~cm}^{-1}$ attributedtoetheric bond ( $\equiv \mathrm{C}-\mathrm{O}-\mathrm{C} \rightleftharpoons$ ).

All above mentioned results indicate the role of the solvent in the process of tar chemical modification due to the formation of oligomeric products. Under the reaction conditions (393 K, $3 \mathrm{~h}$ ) formaldehyde, which was used for the modification, in the presence of the acid catalyst $(\mathrm{HCl})$ is capable to react with the compounds presented in petroleum residues and with the solvent molecules. The reaction results in the formation of arene-formaldehyde resins, which play the role of polymeric modifiers in the resulting products and thus improve their operational characteristics.

\section{Conclusions}

The possibility of using formaldehyde as $37 \%$ aqueous solution to modify petroleum residues in the presence of organic solvents was established. It was determined that the solvents are most effective for the modification of high-viscous materials, bitumen in particular. $n$-Octane in the amount of $20 \mathrm{wt} \%$ relative to the initial residue was found to be the most effective among the solvents under study. The results of IR spectroscopic investigation confirm that arene-formaldehyde resins are not formed during modification process in the presence of toluene, $p$-xylene and naphtha solvent. When using $n$-octane as the solvent, dehydrocyclization of $n$-octane molecules followed by the formation of benzene compounds and condensation of formaldehyde molecules followed by the formation of linear and cyclic ethers can occur.

\section{Acknowledgements}

This work was supported by the National Research Foundation of Ukraine (Grant No. 2020.02/0038). Some experimental results were obtained in collaboration with Laboratory of Advanced Technologies for the Creation and Physico-chemical Analysis of New Compounds and Functional Materials of Lviv Polytechnic National University.

\section{References}

[1] McNally T. (Ed.): Polymer Modified Bitumen. Properties and Characterization. Woodhead Publ., 2011. https://doi.org/10.1533/9780857093721

[2] Airey G.: J. Mater. Sci., 2004, 39, 951.

https://doi.org/10.1023/B:JMSC.0000012927.00747.83

[3] Fang C., Li T., Zhang Z., Jing D.: Polym. Composite, 2008, 29, 500. https://doi.org/10.1002/pc.20390 
[4] Zolotariov V.: Avtoshliakhovyk Ukrainy, 2004, 6, 26.

[5] Poradek S.: Nauka i Tekhnika v Dorognoi Otrasli, 2010, 3, 22.

[6] Malashonok B.: Budivnytsvo Ukrainy, 2005, 3, 43.

[7] Zolotariov V., Simonov A.: Avtoshliakhovyk Ukrainy, 2001, 3, 32.

[8] Sun D., Lu W.: Petrol. Sci. Technol., 2003, 21, 901.

https://doi.org/10.1081/LFT-120017456

[9] Liu Z., Xuan M., Zhao Z. et al.: Petrol. Sci. Technol., 2003, 21, 1317. https://doi.org/10.1081/LFT-120018176

[10] Zolotariov V.: AvtoshliakhovykUkrainy, 2003, 5, 25.

[11] Pyshyev S., Gunka V., Grytsenko Y. et al.: Chem. Chem. Technol., 2016, 10, 637. https://doi.org/10.1016/j.ijprt.2017.05.001

[12] Bratychak M., Chervinskyy T., Astakhova O. et al.: Chem. Chem. Technol., 2010, 4, 325.

https://doi.org/10.23939/chcht04.04.325

[13] BratychakM., GrynyshynO., AstakhovaO. et al.: Ecol. Chem. Eng. S, 2010, 17, 309.

[14] Grynyshyn O., Bratychak M., Krynytskiy V. et al.: Chem. Chem. Technol., 2008, 2, 47.

[15] Strap G., Astakhova O., Lazorko O. et al.: Chem. Chem. Technol., 2013, 7, 279. https://doi.org/10.23939/chcht07.03.279 [16] Bratychak M., Iatsyshyn O., Shyshchak O. et al.: Chem. Chem. Technol., 2017, 11, 49. https://doi.org/10.23939/chcht11.01.049

[17] Sidun I., Solodkyy S., Shved M. et al.: Chem. Chem. Technol., 2019, 13, 489. https://doi.org/10.23939/chcht13.04.489

[18] Demchuk Y., Gunka V., Pyshyev S. et al.: Chem. Chem. Technol., 2020, 14, 251. https://doi.org/10.23939/chcht14.02.251 [19] Pyshyev S., Demchuk Yu., Gunka V. et al.: Chem. Chem. Technol., 2019, 13, 212. https://doi.org/10.23939/chcht13.02.212 [20] Gunka V., Demchuk Yu., Sidun I. et al.: Road Mater. Pavement Des., 2020. https://doi.org/10.1080/14680629.2020.1808518

[21]Gunka V., Demchuk Yu., Pyshyev S. et al.: Pet. Coal, 2018, 60, 1199.
[22] Demchuk Yu., Sidun I., Gunka V. et al.: Chem. Chem. Technol., 2018, 12, 456. https://doi.org/10.23939/chcht12.04.456 [23] Gunka, V., Demchuk, Y., Sidun, I. et al.: Pet. Coal, 2020, 62, 420.

[24] Moshchinskaya N.: Polimernye materialy na osnove aromaticheskikh uglevodorodov i formal'degida.Tehnika.Kyiv.1969. [25] Gutsaliuk V., Nevskyi V., Safronovs A.: ArenphenolAldehydnye Oligomery. Nauka, Alma-Aty 1986.

Received: November 12, 2020 / Revised: November 30, 2020 / Accepted: December 22, 2020

\section{ОДЕРЖАННЯ БІТУМУ, МОДИФІКОВАНОГО НИЗЬКОМОЛЕКУЛЯРНИМИ ОРГАНІЧНИМИ СПОЛУКАМИ ІЗ НАФТОВИХ ЗАЛИШКІВ. 1. ВПЛИВ ПРИРОДИ РОЗЧИННИКА НА ВЛАСТИВОСТІ НАФТОВИХ ЗАЛИШКІВ, МОДИФІКОВАНИХ ФОРМАЛЬДЕГЦДОМ}

\footnotetext{
Анотація. Вивчена можливість модифікування нафтових залииків (гудрону і окисненого бітуму) формальдегідом у вигляді 37\% водного розчину за температури $393 \pm 3 \mathrm{~K}$ впродовж 3 годин в присутності органічного розчинника з використанням як каталізатор хлорної кислоти. Як органічний розчинник використано толуен, $n$ ксилен, нафтовий сольвент і н-октан в кількості від 0 до $40 \%$ мас. на вихідний нафтовий залишок. ІЧ-спектроскопічними дослідженнями встановлено утворення між молекулами формальдегіду та сполуками, що містяться у нафтовому залишку й молекулами розчинника смоло подібних продуктів, які впливають на експлуатаційні характеристики нафтових залишків.
}

Ключові слова: нафтові залишки, формальдегід, органічні розчинники, модифіковані бітуми, ІЧ-спектроскопія. 